\author{
B.K. Rakhadilov ${ }^{1}$, Y.Y. Tabiyeva ${ }^{*}{ }^{, 1,2}$, G.K. Uazyrkhanova ${ }^{2}$, L.G. Zhurerova $^{2}$, N.A. Popova ${ }^{3}$ \\ ${ }^{1}$ S. Amanzholov East-Kazakhstan State University, Ust-Kamenogorsk, Kazakhstan; \\ ${ }^{2}$ D. Serikbayev East-Kazakhstan State Technical University, Ust-Kamenogorsk, Kazakhstan; \\ ${ }^{3}$ Tomsk State Architecture and Building University, Tomsk, Russia \\ (E-mail: erkezhan.tabieva@mail.ru)
}

\title{
Effect of electrolyte-plasma surface hardening on structure wheel steel 2
}

\begin{abstract}
This paper examines the influence of electrolyte-plasma surface hardening on the structure and microhardness of wheel steel mark 2. In the work electrolyte-plasma surface hardening was carried out in an electrolyte made from an aqueous solution $10 \%$ carbamide $\left(\mathrm{NH}_{2}\right)_{2} \mathrm{CO} 20 \%$ sodium carbonate $\mathrm{Na}_{2} \mathrm{CO}_{3}$. The processing time was 2 seconds, Tmax $=850-900{ }^{\circ} \mathrm{C} ; \mathrm{U}=320 \mathrm{~V} ; \mathrm{I}=40 \mathrm{~A}$. According to the results of the scanning transmission electron microscopy, the electrolyte-plasma surface hardening caused a change in the morphological constituents of mark 2 steel. In the initial state, the matrix of steel is a $\alpha$-phase, the morphological components of which are fragmented ferrite, unfragmented ferrite and pearlite. After electrolytic-plasma surface hardening, a batch, high-temperature plate and low-temperature plate martensit is formed on the surface of the sample. Investigations have been carried out on microhardness determination on cross-section of wheel steel samples after quenching in aqueous solution of electrolyte. It is found that after electrolytic-plasma surface hardening, the microhardening values of this hardened surface layer increased $\sim 3$ times compared to the steel matrix, and the thickness of the hardened layer is 1000-1500 microns.
\end{abstract}

Keywords: electrolytic-plasma surface hardening, wheel steel, transmission electron microscopy, fine structure, microhardness, morphology, martensite.

\section{Introduction}

It is known, that the development of new materials with hardened surface and layers in machinery and metallurgy can promote better performance characteristics of the structure, higher reliability as well as provide energy and resource saving [1-2]. The effective method of surface hardening of iron-carbon steels is the treatment of electrolytic plasma, when due to high-speed heating and cooling in the thermal influence zone, the structure changes as a result of phase transitions that provide the necessary operational characteristics of the working surface of the parts [3-4]. An important feature of plasma hardening is the possibility of its effective application for additional hardening of the surface of parts that have passed conventional volumetric thermal treatment.

The problem of service life and economical use of railway products is closely related to the strength and tribological properties of products made of wheel steels [5-6]. To improve the already existing properties of wheel steels, it is necessary to carefully and comprehensively analyze the influence of surface hardening on the steel structure, since it is by changing the structural components that it is possible to achieve the necessary mechanical characteristics of the working surfaces of the parts.

In view of this fact, given research is focused on studying phase composition, fine structure and mechanical properties of wheel steel 2 before electrolyte plasma surface hardening and after that one.

\section{Material and methods of research}

Wheel steel mark 2 applied in fabricating railway wheel-sets tires has been chosen as study object. According to GOST 398-96 the condition of heat treatment of mark 2 wheel steel in initial condition: In its initial state steel mark 2 represents material exposed to hardening from $890^{\circ} \mathrm{C}$ for $2-2.5$ hours with cooling in warm water $\left(30-60^{\circ} \mathrm{C}\right)$ followed by tempering at $580^{\circ} \mathrm{C}$ for $2.5-3$ hours.

Some steel samples were cut out of the wheel tire as parallelepiped in size $15 \times 15 \times 10 \mathrm{~mm}^{3}$. The sample was free from deformation and thermal effect under slow cutting speed and low load. According to GOST 398-96, chemical composition of steel (in \%) is C-0.57-0.65; Mn-0.50-0.90; Si-0.22-0.45; V — not exceeded $0.10 ; \mathrm{S}$ - not exceeded 0.030 and $\mathrm{P}$ - not exceeded 0.035 respectively.

Given experimental research was realized by joint efforts of specialists in National Research Laboratory for collective use, S. Amanzholov East Kazakhstan State University (EKSU), Center of Advanced Develop- 
ment «VERITAS», D. Serikbayev East Kazakhstan State Technical University (EKSTU) and Research laboratories of Tomsk State University of Architecture and Building (RF).

The fine structure was studied qualitatively and quantitatively by transmission electron diffraction microscopy (TEM) technique on thin foils in EM-125 electron microscope at an accelerating voltage of $125 \mathrm{kV}$. Working magnification was equal to 25.000 times in the microscope column. The morphology of the surface structure was studied on the raster electron microscope JSM-6390LV, equipped with the energy-dispersive analysis prefix INCA Energy Penta FET X3. The microhardness of steel samples was measured in PMT-3M machine in accordance with GOST 9450-76, with loads on the indenter of 100g and holding time for 10 seconds.

Electrolyte-plasma surface hardening of the steel was carried out in the cathode mode in electrolyteplasma treatment machine [7], scheme (fig.1a) and processing (fig.1b) shown in Figure 1.
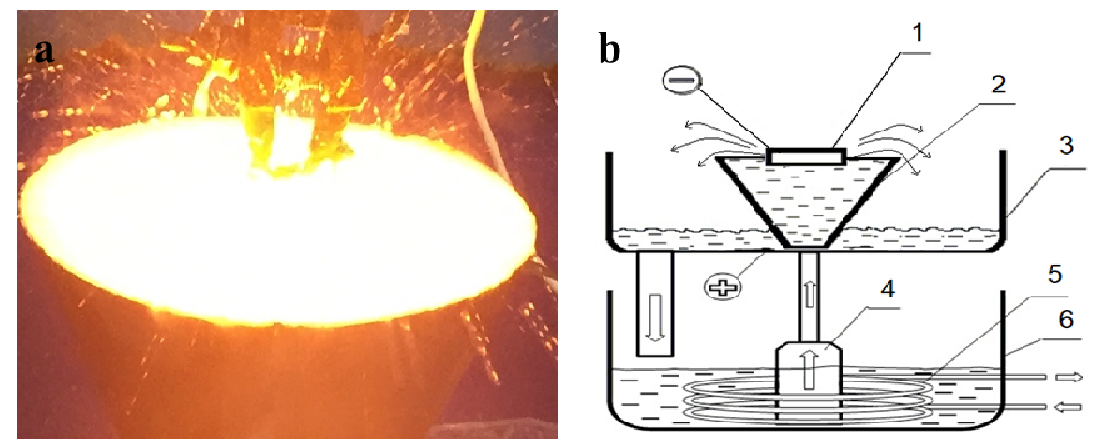

1-in-process part; 2 - conic stainless steel electrolytic cell;

3- bottom plate; 4-pump; 5- heat exchanger; 6- bath filled with electrolyte

Figure 1. Process of processing of an electrolyte plasma sample (a) and functional diagram (b) of the machine

High-current rectifier with output power of $360 \mathrm{~V} / 60 \mathrm{~A}$ as DC was used as a power source. The samples were processed by rapid heating for 2 seconds followed by cooling in a flowing electrolyte. The process was realized under the following parameters: electrolyte composition (\%, mass): $10 \%$ urea $\left(\mathrm{NH}_{2}\right)_{2} \mathrm{CO}+20 \%$ sodium carbonate $\mathrm{Na}_{2} \mathrm{CO}_{3}+70 \%$ water, processing lasted for 2 seconds, $\mathrm{T}_{\max }=850-900{ }^{\circ} \mathrm{C}$; U= $320 \mathrm{~V}$; $\mathrm{I}=40 \mathrm{~A}$.

\section{Results and its discussion}

The results of experimental studies on structural-phase state of steel mark 2 showed that in its initial state the steel matrix represents $\alpha$-phase - solid solution of carbon and alloying elements in $\alpha$-Fe with BCC matrix.

Lamellar pearlite and ferrite are morphological components of $\alpha$ - phase. Lamellar perlite, almost ideal, i.e. it is a conglomerate of alternating parallel plates ferrite and cementite [8]. Ferrite ( $\alpha$-phase) in the pearlit has a volumetric-centered cubic (BCC) crystal lattice.

Mutual parallelism of the lamellas [9] means that, firstly, different lamellas of the same phase within the colony have the same orientation and, secondly, mutual orientation of two phases (their orientation ratio) provides best coupling of two crystal lattices along the habit surface of the lamellas. It is established [10] that Bagaryatsky orientation relationship is observed between ferrite and cementite in nearly every pearlite colony, which is not related to the carbon content in the steel. It should be noted that steel alloying doesn't have an effect on crystallographic characteristics within the pearlite [10].

The volume ratio of lamellar pearlite is $35 \%$ along the material (table 1 ).

It should be noted that the planning method was used to determine the volume fraction, which is reduced to the measurement of the total area of sections of this structural component on a certain area of the foil.

The conclusion of the working formula of this method is based on the principle of Cavalieri-AkerGlagolev $[11 ; 50]$. It postulates the relationship between the Area $\left(\mathrm{P}_{\mathrm{S}}\right)$ and Volume $\left(\mathrm{P}_{\mathrm{V}}\right)$ shares:

$$
P_{V}=P_{S}
$$


This is one of the fundamental relationships of stereology postulated by S.A. Saltykov $[11 ; 51]$. The working formula of the planning method has the following form:

$$
P_{S}=\frac{S}{L^{2}}=\frac{V}{L^{3}}=P_{V},
$$

Where $\mathrm{S}$ and $\mathrm{V}$ are the area and volume occupied by the corresponding structural component in the sample element representing the L-rib cube.

Ferrite in the initial state of the mark 2 steel is present in the form of non-segmented and fragmented ferrites. The volume share of non-segmented ferrite is $\sim 10 \%$. The volume of fragmented ferrite is $55 \%$. The surface hardening carried out resulted in the formation of packet-plate martensite. The volume share of pacts of martensite is $60 \%$, plate low-temperature martensite is $10 \%$, plate high-temperature martensite is $30 \%$.

It is also known that martensite transformation almost always does not take place completely [8-10]. This leads to the presence in the material of a certain amount of residual austenite ( $\gamma$ phase). The crystal lattices of residual austenite and the $\alpha$-phase, regardless of the type and location of residual austenite, are always interconnected by the Kurdyumov - Sachs orientation relation [11; 67].

The volume fraction of residual austenite ( $\gamma$-phase) in lath martensite is $6.5 \%$.

Studies have shown that in mark 2 steel after surface hardening inside all crystals of martensitis there are particles of cement. Crystalline grates of cement and $\alpha$-phase are connected among themselves by the orientation ratio of Bagaryatskiy [11;20]. The volume fraction of cementite in lath martensite is $0.27 \%$, in low-temperature lamellar martensite is $0.95 \%$ and in high-temperature lamellar martensite is $2 \%$. (table 1 ). The volume fraction of cement $\left(\delta_{\mathrm{FeC}}\right)$ was calculated using the formula [12]:

$$
\delta_{\mathrm{Fe}_{3} \mathrm{C}}=\frac{\mathrm{V}_{\mathrm{Fe}_{3} \mathrm{C}}}{t \cdot r^{2}},
$$

Where $V_{\mathrm{Fe}_{3} \mathrm{C}}$ - is the average volume of one particle of cement, $\mathrm{t}-$ is the thickness of the foil, $\mathrm{r}$ - is the average distance between particles.

Figure 2 shows an electron-microscopic image of the fine structure of mark 2 steel before and after electrolytic-plasma surface hardening. Mark 2 steel is ferrite-pearlite steel, as evidenced by the microscopic image of this steel in the delivery states (Fig.2a) where $\mathrm{P}$-pearlite is marked in the image, FF - fragmented ferrite. The white arrow marks a chain of small fragments on the border of grains «pearlit - ferrite». In the microscopic image, after plasma surface hardening (Fig.2b), the structure of the wheel steel consists of packet-plate martensite. Figure $2 \mathrm{~b}$ shows L-packet martensit, Figure 2c shows LL-lamellar low-temperature martensit, HL-lamellar high-temperature martensit. On the boundaries of martensitic crystals - interlayer of residual austenite $(\gamma)$.
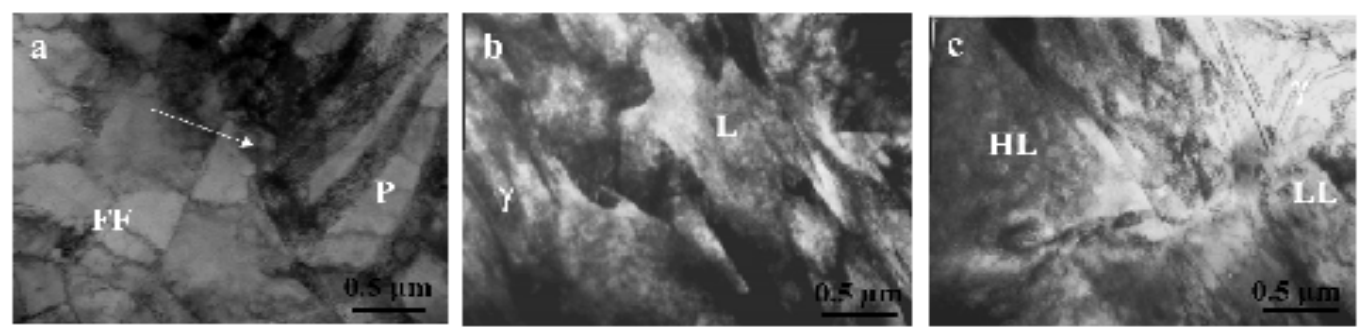

Figure 2. Electron microscopic image of fine structure of steel 2 before (a) and after (b, c) electrolyte-plasma surface hardening

Studies have shown that surface hardening of steel 2 subjected to electrolyte-plasma surface hardening in an electrolyte plasma, structural changes were detected.

Figure 3 (a-c) shows the microstructure of the steel cross section after treatment in an electrolyte containing an aqueous solution of $10 \%$ carbamide $\left(\mathrm{NH}_{2}\right)_{2} \mathrm{CO}$ and $20 \%$ sodium carbonate $\mathrm{Na}_{2} \mathrm{CO}_{3}$ with a treatment time of 2 seconds at a temperature of $860^{\circ} \mathrm{C}$.

As can be seen from Figure 3, the electrolyte-plasma surface hardening led to a change in the microstructure of the cross section, where the zoning of structures typical of electrolyte-plasma treatment is visible. The cross-sectional structure consists of 3 zones: 1 zone - a zone of surface hardening with a thickness of 1000-1500 $\mu \mathrm{m}, 2$ zone - a zone of thermal influence, 3 zone - a matrix. 

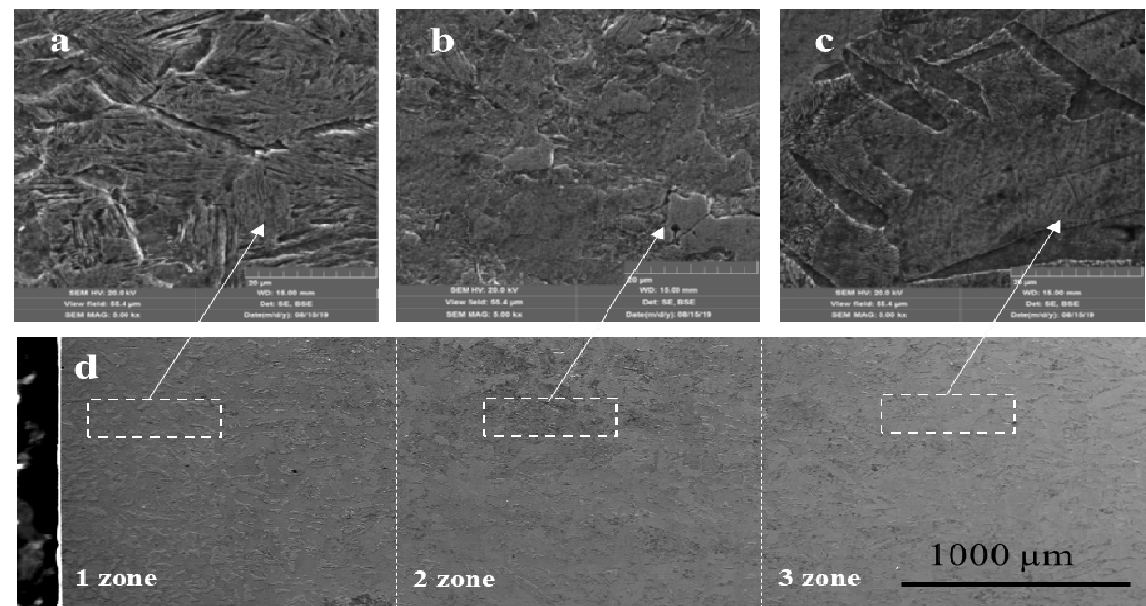

a) a hardened layer; b) a transition layer; c) non-hardened layer; d) general view

Figure 3. Pictures of the microstructure along the cross section of steel mark 2 after electrolyte-plasma surface hardening

Phase composition of steel mark 2 before and after electrolyte-plasma surface hardening

\begin{tabular}{|c|c|c|c|c|c|c|c|c|c|}
\hline \multirow[b]{3}{*}{$\begin{array}{c}\text { Phase } \\
\text { Composition Parameters }\end{array}$} & \multicolumn{3}{|c|}{ before EPSH } & \multicolumn{6}{|c|}{ after EPSH } \\
\hline & \multirow[b]{2}{*}{ : } & \multicolumn{2}{|c|}{ Ferrite } & \multicolumn{3}{|c|}{ Martensite } & \multirow[b]{2}{*}{$\begin{array}{l}\text { The propor- } \\
\text { tion of } \gamma \text {-Fe } \\
\text { in LM, } \%\end{array}$} & \multirow[b]{2}{*}{$\begin{array}{l}\text { Cementite } \\
\text { in LM, \% }\end{array}$} & \multirow[b]{2}{*}{$\begin{array}{c}\mathrm{M}_{23} \mathrm{C}_{6} \\
\text { carbides in } \\
\text { LM, \% }\end{array}$} \\
\hline & & 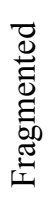 & 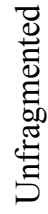 & 蔦 & $\begin{array}{c}\text { Lamellar } \\
\text { low- } \\
\text { temperature }\end{array}$ & $\begin{array}{l}\text { Lamellar } \\
\text { high- } \\
\text { temperature }\end{array}$ & & & \\
\hline Volume fraction $\left(\mathrm{P}_{\mathrm{V}}\right), \%$ & 35 & 55 & 10 & 60 & 10 & 30 & 6,5 & 2 & 2.7 \\
\hline Totally in the material, $\%$ & \multicolumn{3}{|c|}{100} & \multicolumn{3}{|c|}{100} & 7.2 & 0.86 & 0.8 \\
\hline
\end{tabular}

${ }^{*}$ Note: Data were obtained according to the calculations by formulas [1-3] from electron microscopic images.

As is known, one of the most important properties of the surface layer, which significantly affects the strength characteristics, is microhardness, the value of which in the initial state (matrix) of steel mark 2 is $140 \mathrm{HV}$. In this work, we studied the changes in the microhardness of a specimen of steel mark 2 over a cross section after electrolytic plasma surface hardening. According to the results obtained, the average microhardness in the surface hardening zone is $\sim 420 \mathrm{HV}$, in the heat-affected zone it is $\sim 260 \mathrm{HV}$ and, accordingly, in the steel mark 2 matrix, the microhardness remains unchanged.

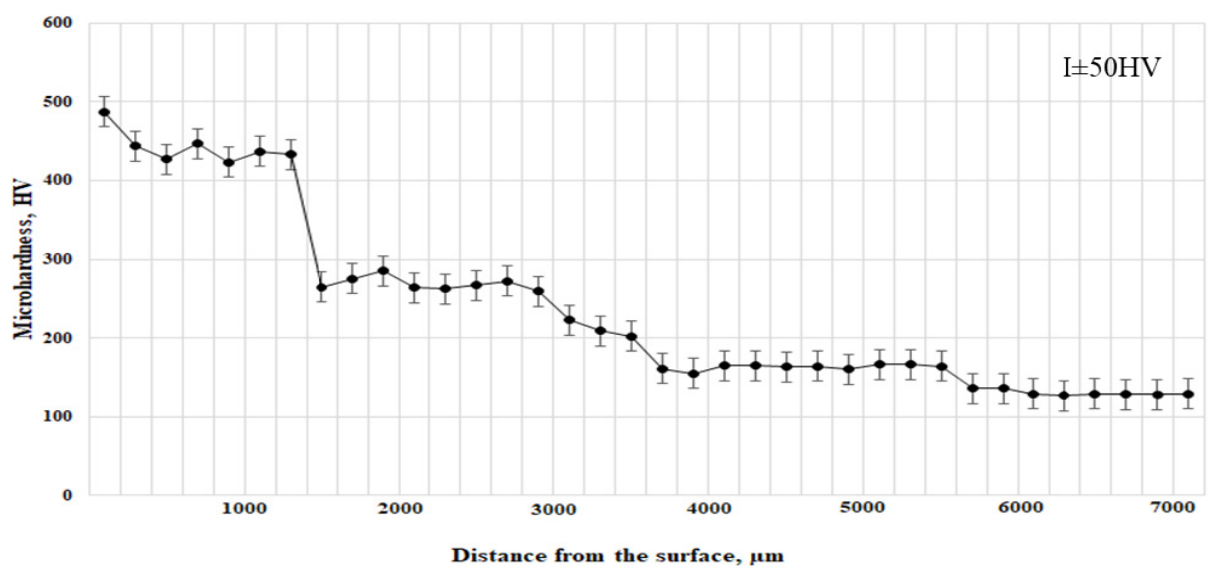

Figure 4. Distribution of microhardness over the cross section of steel mark 2 after electrolyte-plasma surface hardening 


\section{Conclusion}

In conclusion, the analysis of study results of phase composition, fine structure and mechanical properties of wheel steel mark 2 before and after electrolyte-plasma surface hardening has shown:

- In its initial state, matrix of steel mark 2 represents 1) $\alpha$-phase the volume ratio of unfragmented ferrite is $\sim 10 \%$ and $55 \%$ of fragmented one respectively, 2 ) pearlite with a volume of $\sim 35 \%$;

- It was revealed that the morphological components of the structure of steel mark 2 after EPSH at Tmax $=850-900{ }^{\circ} \mathrm{C}$ and the exposure time of $2 \mathrm{~s}$ are: martensite in the form of packet martensite with a volume fraction of $60 \%$, lamellar low-temperature and lamellar high-temperature martensites with volume fractions of $\sim 10 \%$ and $\sim 30 \%$, respectively;

- It was determined that electrolyte-plasma surface hardening leads to a change and hardening of the surface layer of mark 2 steel, the thickness of the hardened layer is $\sim 1000-1500 \mu \mathrm{m}$, and the microhardness increases by $\sim 3$ times.

The work was supported as part of scientific-research grant of the Ministry of Education and science of the Republic of Kazakhstan (BR 05236748).

\section{References}

1 Tabieva, E. Influence of Electrolyte-Plasma Hardening Technological Parameters on the Structure and Properties of Banding Steel 2 / E.E. Tabieva., L.G. Zhurerova, D. Baizhan // Key Engineering Materials. — 2020. — Vol. 839. — P. 57-62.

2 Wang L. Microstructure features on rolling surfaces of railway rails subjected / L. Wang, A. Pyzalla, W. Stadlbauer // Journal of Materials and Engineering. - 2003. - A359. - P. 31-43.

3 Rakhadilov B.K. Electrolyte-plasma surface hardening of $65 \mathrm{G}$ and $20 \mathrm{GL}$ low-alloy steels / B.K. Rakhadilov, L.G. Zhurerova, A.V. Pavlov // Bulletin of the University of Karaganda-Physics. - 2016. - Vol. 4(84). - P. 8-13.

4 Rakhadilov B.K. Change in high-temperature wear resistance of high-speed steel by plasma nitriding / B.K. Rakhadilov, L.G. Zhurerova, M. Scheffler, A.K. Khassenov.// Bulletin of the University of Karaganda-Physics. — 2018. - Vol. 3(91). - P. 59-65.

5 Rakhadilov B.K. Plasma-electrolytic Nitriding of 0.3Cr-1Mn-1Si-Fe Construction Steel / B.K. Rakhadilov, E.E. Tabieva., L.G. Zhurerova // METAL 2019 - 28th International Conference on Metallurgy and Materials, Conference Proceedings. — 2019. - P. 1174-1179.

6 Wang M. Effects of high-temperature deformation and cooling process on the microstructure and mechanical properties of an ultrahigh-strength pearlite steel / M. Wang, F. Zhang, Z. Yang // Materials \& Design. — 2017. — Vol. 114. — P. $102-110$.

7 Skakov M.K. Installation of electrolytic-plasma processing / M.K. Skakov, B.K. Rahadilov, D.B. Zarva, A.V. Gulkin // Innovative patent for the invention of the Republic of Kazakhstan: IPC C255F 7/00 — № 29978 / Application. 03/02/2014; Publ. 15.06.2015, Bul. № 6.

8 Lobanov M.L. Investigation of Special Misorientations in Lath Martensite of Low Carbon Steel Using the Method of Orientation Microscopy / M.L. Lobanov, G.M. Rusakov, A.A. Redikul'tsev, S.V. Belikov, M.S. Karabanalov, E.R. Struina // The Physics of Metals and Metallography. - 2016. - Vol. 117. - P. 254-259.

9 Albou A. Nanoscale characterization of the evolution of the twin-matrix orientation in Fe-Mn-C twinning-induced plasticity steel by means of transmission electron microscopy orientation mapping / A. Albou, M. Galceran, K. Renard, S. Godet, P.J. Jacques // Scripta Materialia. - 2013. - Vol. 68. - P. 400-403.

10 Кащенко М.П. Связь различных габитусов с вариантами ориентационных соотношений при $\gamma-\alpha$ мартенситном превращении в динамической теории / М.П. Кащенко, К.Н. Джемилев, В.Г. Чащина // Фундаментальные проблемы современного материаловедения. - 2012. - № 1. - С. 50-56.

11 Гришунин В.А. Повышение усталостной долговечности рельсовой стали электронно-пучковой обработкой: дис. канд. техн. наук: 05.16.01 - «Металловедение и термическая обработка металлов и сплавов» / В.А. Гришунин. — Новокузнецк, 2014. - 181 с. $232 \mathrm{c}$.

12 Курдюмов Г.В. Превращения в железе и сталях / Г.В. Курдюмов, Л.М. Утевский, Р.И. Энтин. — М.: Наука, 1977. -

Б.К. Рахадилов, Е.Е. Табиева, Г.К. Уазырханова, Л.Г. Журерова, Н.А. Попова

\section{Электролитті-плазмалық беттік шынықтырудың 2 маркалы дөңгелек болаттың құрылымына әсері}

Мақала электролитті-плазмалық беттік шынықтырудың 2 маркалы дөңгелек болат үлгілерінің жұмыс бетінің құрылымы мен микроқаттылығына әсерін зерттеуге арналған. Жұмыс электролитті-плазмалық беттік шыңдау $10 \%$ карбамид $\left(\mathrm{NH}_{2}\right)_{2} \mathrm{CO}+20 \%$ натрий карбонатының $\mathrm{Na}_{2} \mathrm{CO}_{3}$ сулы ерітіндісінен 
жасалған электролитте жүзеге асырылған. Өңдеу уақыты 2 сек, $\mathrm{T}_{\max }=850-900{ }^{\circ} \mathrm{C} ; \mathrm{U}=320 \mathrm{~V} ; \mathrm{I}=40 \mathrm{~A}$ болды. Жарық беретін электрондық микроскопияның нәтижелеріне сәйкес электролитті-плазмалық беттік шыңдау 2 маркалы болаттың морфологиялық құраушыларының өзгеруіне алып келгенін көрсетеді. Бастапқы жағдайында болаттың морфологиялық құраушылары фрагменттелген феррит, фрагменттелмеген феррит және перлиттен құралып, ал матрица $\alpha$-фазадан тұрады. Электролиттіплазмалық беттік шынықтырудан кейін үлгінің бетінде пакетті (рейкалы, тақтайша тәріздес), жоғары температуралы қатпарлы және төмен температуралы қатпарлы мартенсит түзіледі. Электролиттің сулы ерітіндісінде шынықтырылғаннан кейін дөңгелек болат үлгілерінің көлденең қимасы бойынша микроқаттылықты анықтауға зерттеулер жүргізілген. Электролитті-плазмалық беттік шынықтырудан кейін осы беттік қабаттың микроқаттылығының мәні болаттың матрицасымен салыстырғанда 3 есе өскенін, ал шынықтырылған қабаттың қалыңдығы 1000-1500 мкм құрайтынын көрсеткен.

Кілm сөздер: электролитті-плазмалық беттік шынықтыру, дөңгелек болат, трансмиссиялық электрондық микроскопия, жұқа құрылым, микроқаттылық, морфология, мартенсит.

Б.К. Рахадилов, Е.Е. Табиева, Г.К. Уазырханова, Л.Г. Журерова, Н.А. Попова

\title{
Влияние электролитно-плазменной поверхностной закалки на структуру колесной стали марки 2
}

\begin{abstract}
Статья посвящена исследованию влияния электролитно-плазменной поверхностной закалки на структуру и микротвердость рабочей поверхности образцов колесной стали марки 2. Электролитноплазменную поверхностную закалку осуществляли в электролите из водного раствора 10-процентного карбамида $\left(\mathrm{NH}_{2}\right)_{2} \mathrm{CO}+20$-процентного карбоната натрия $\mathrm{Na}_{2} \mathrm{CO}_{3}$. Время обработки составляло 2 сек, $\mathrm{T}_{\max }=850-900{ }^{\circ} \mathrm{C} ; \mathrm{U}=320 \mathrm{~V} ; \mathrm{I}=40 \mathrm{~A}$. Согласно результатам просвечивающей электронной микроскопии электролитно-плазменная поверхностная закалка привела к изменению морфологических составляющих стали марки 2. В исходном состоянии матрица стали представляет собой $\alpha$-фазу, морфологическими составляющими которой являются фрагментированный феррит, нефрагментированный феррит и перлит. После электролитно-плазменной поверхностной закалки на поверхности образца формируется пакетный, высокотемпературный пластинчатый и низкотемпературный пластинчатый мартенсит. Проведены исследования на определение микротвердости по поперечному сечению образцов колесной стали после закалки в водном растворе электролита. Установлено, что после электролитноплазменной поверхностной закалки значение микротвердости данного закаленного поверхностного слоя повысилось в $\sim 3$ раза по сравнению с матрицей стали, а толщина закаленного слоя составила $1000-1500$ мкм.
\end{abstract}

Ключевые слова: электролитно-плазменная поверхностная закалка, колесная сталь, просвечивающая электронная микроскопия, тонкая структура, микротвердость, морфология, мартенсит.

\section{References}

1 Tabieva, E., Zhurerova, L., \& Baizhan, D. (2020). Influence of Electrolyte-Plasma Hardening Technological Parameters on the Structure and Properties of Banding Steel 2. Key Engineering Materials, 839, 57-62.

2 Wang, L., Pyzalla, A., \& Stadlbauer, W. (2003). Microstructure features on rolling surfaces of railway rails subjected. Journal of Materials and Engineering, A 359, 31-43.

3 Rakhadilov, B.K., Zhurerova, L.G., \& Pavlov, A.V. (2016). Electrolyte-plasma surface hardening of $65 \mathrm{G}$ and $20 \mathrm{GL}$ lowalloy steels. Bulletin of the University of Karaganda-Physics, 4, 84, 8-13.

4 Rakhadilov, B.K., Zhurerova, L.G., Scheffler, M., \& Khassenov, A.K. (2018). Change in high-temperature wear resistance of high-speed steel by plasma nitriding. Bulletin of the University of Karaganda-Physics, 3, 91, 59-65.

5 Rakhadilov, B.K., Tabieva, E., \& Zhurerova, L. (2019). Plasma-electrolytic Nitriding of 0.3Cr-1Mn-1Si-Fe Construction Steel. METAL 2019 - 28th International Conference on Metallurgy and Materials. Conference Proceedings, 1174-1179.

6 Wang, M., Zhang, F., \& Yang, Z. (2017). Effects of high-temperature deformation and cooling process on the microstructure and mechanical properties of an ultrahigh-strength pearlite steel. Materials \& Design, 114, 102-110.

7 Skakov M.K., Rahadilov B.K., Zarva D.B., \& Gulkin A.V. Installation of electrolytic-plasma processing. Innovative patent for the invention of the Republic of Kazakhstan: IPC C255F 7/00 — № 29978 / Application. 03/02/2014; Publ. 15.06.2015, Bul. № 6.

8 Lobanov, M.L., Rusakov, G.M., Redikul'tsev, A.A., Belikov, S.V., Karabanalov, M.S., \& Struina, E.R. (2016). Investigation of Special Misorientations in Lath Martensite of Low Carbon Steel Using the Method of Orientation Microscopy. The Physics of Metals and Metallography, 117, 254-259.

9 Albou, A., Galceran, M., Renard, K., Godet S., \& Jacques, P.J. (2013). Nanoscale characterization of the evolution of the twin-matrix orientation in Fe-Mn-C twinning-induced plasticity steel by means of transmission electron microscopy orientation mapping. Scripta Materialia, Vol. 68, 400-403.

10 Kashchenko, M.P., Dzhemilev, K.N., \& Chashchina, V.G. (2012). Sviaz razlichnykh habitusov s variantami orientatsionnykh sootnoshenii pri $\gamma$ - $\alpha$-martensitnom prevrashchenii $v$ dinamicheskoi teorii [The variety of different habitus with variants of orientation 
relations at $\gamma-\alpha$ martensitic transformation in dynamic theory]. Fundamental problems of modern materials science, 9,456 [in Russian].

11 Grishunin, V.A. (2014). Povyshenie ustalostnoi dolhovechnosti relsov stali elektronno-puchkovoi obrabotkoi [Increase of fatigue durability of rail steel by electron-beam processing]. Candidate's thesis. Novokuznetsk [in Russian].

12 Kurdyumov, G.V., Utevsky, L.M., \& Entin, R.I. (1977). Prevrashcheniia v zheleze $i$ staliakh [Transformations in iron and steel]. Moscow: Nauka [in Russian]. 